\title{
WALT WHITMAN AND THE QUAKER WOMAN
}

\section{Christina Davey}

FROM WhITMAN's PERSPECTIVE, many women in nineteenth-century American society were unhealthy, isolated, and silent. Whitman saw "hundreds of spleeny, sickly, feeble girls" and attributed their condition to lack of exercise and hard work, and to their conforming to standards of fashion, especially "thin shoes" and "muslin dresses." Moreover, Whitman explained that women's "nervous sensations," "habitual despondency," and "dissatisfaction" prevented married women and their husbands from experiencing joy, thereby weakening the relationships. ${ }^{2}$ And he lamented the physical and emotional vacuum in which many unmarried women lived as they limited their activities to handiwork and Sunday school after having been overlooked by men as marriage partners. ${ }^{3}$ Even when women physically moved away from established society, they continued to conform to the social conventions of the area they had left behind, as did the women Whitman had seen on his 1879 trip to Kansas City and Denver. ${ }^{4}$ Whitman challenged women to leave the restricted lives they had modeled after those depicted in novels. "[G]ive up toys and fictions," he wrote, "and launch forth, as men do, amid real, independent, stormy life." $" 5$

Critics are divided in their views of Whitman's attitude toward women. Some see Whitman presenting women in a positive light. Harold Aspiz, Betsy Erkkila, Muriel Kolinsky, Kay F. Reinartz, Judy Womack, and, recently, Sherry Ceniza are among those who have praised Whitman for not limiting women to motherhood even though he valued that role for them. ${ }^{6}$ However, others take an essentially negative view of Whitman's depictions of women. D. H. Lawrence sees Whitman's women as "depressing" and claims the poet viewed women not as individuals with souls, but merely as "a submissive function," limited to conceiving babies and giving birth to them. ${ }^{7}$ Arthur Wrobel agrees with Lawrence's assessment, arguing that Whitman "requires the willing submission of women to motherhood." Whitman's women could, however, begin to work for their own equality with men, Wrobel claims, but only after they had fulfilled their duty to bear and rear children who would bring about "the complete transformation of society."

Other critics see contradictions in Whitman's depictions of women. M. Jimmie Killingsworth, for example, explains that Whitman does not 
limit women to motherhood. The poet advocates that women explore areas outside traditional roles. And Killingsworth sees incongruities in Whitman's portrayal of the sexual woman as both "mystic" and "erotic." These depictions of women as both sexual being and mother "collide rather than meld," he asserts. Moreover, Killingsworth sees Whitman's women as sexually "incomplete," able to attain wholeness only by participating in a heterosexual relationship..$^{9}$ Robyn Wiegman agrees, contending that Whitman, despite his intention to depict women in heterosexual relationships in a positive light, limits women's roles to procreation and motherhood, a contradiction, she says, in light of his professed equality for women. ${ }^{10}$

In their examinations of Whitman's poetic depictions of women, critics have neglected to consider Whitman's knowledge of Quaker women and the extent of Quaker influences on him. This oversight has occurred even though William Sloane Kennedy, in 1890, saw Quakerism as a source of Whitman's conviction of the equality of women and men, ${ }^{11}$ and in spite of the fact that several critics have discussed the compatibility of Whitman's spiritual views with Quaker belief. ${ }^{12}$ Reinartz does recognize Whitman's admiration for Quaker women in her brief examination of Quaker influences on four women Whitman presents in Democratic Vistas, noting that these women reflect characteristics of Quaker women with whom Whitman was familiar. However, she focuses her discussion on Whitman's prose. Moreover, even though she includes Mary Whitall Smith Costelloe among the women Whitman admired, she fails to note that she was a Quaker. ${ }^{13}$

An examination of Whitman's poetic depictions of women in light of his knowledge of Quaker women and Quaker influences on his spiritual views is long overdue. Such an examination helps resolve some of the confusion surrounding Whitman's portrayal of women. Women in his work are not as passive as they appear to some critics. He in fact portrays women as active participants in American society, but the key to grasping the nature of that active participation lies in understanding "passivity" as Quakers do.

Whitman associated with Quakers from his early childhood on, and he was exposed to Quaker practice and belief both within his family and outside it. However, he never became a Quaker, he said, because he did not want to be bound by the restrictions of any religion (Traubel, 2:19). Naomi Williams (d. 1826), his maternal grandmother the nearest relation to have been reared a Quaker, ${ }^{14}$ followed Quaker traditions. ${ }^{15}$ Whitman recalled his grandmother wore a Quaker cap $(P W, 1: 8)$ and dressed in the manner of Quakers. ${ }^{16}$ Moreover, John Burroughs stated that she was "deeply intuitive and spiritual"; ${ }^{17}$ quite possibly, then, Williams held family devotions, a Quaker custom. J. William Frost explains that Quaker parents encouraged their children to experience their own revelations 
by following the parents' example during these devotions. ${ }^{18}$ The picture of his grandmother at her devotions would likely have impressed the young Whitman. Their relationship seems to have been quite close and loving, and Whitman missed his grandmother dearly when she died (Allen, Solitary, 13). Whitman remembered that she was "fond of children" ( $D B N, 1: 267 \mathrm{n})$, and surely the young Whitman was among those children upon whom she bestowed her affection. He described her, moreover, as "a mild, gentle, and sweet tempered woman, ... remarkably generous and hospitable in disposition" ( $D B N, 1: 267 \mathrm{n})$, and Burroughs added that she was a woman "of sweet sensible character" (quoted in Whitman, $P W, 1: 9)$. Thus, within this loving relationship, and before the age of seven (his age at his grandmother's death) Whitman likely learned something of the actions and thinking of Quakers.

Although Whitman's mother, Louisa Van Velsor (1795-1873) was not Quaker, Whitman recognized qualities in her that he identified as Quaker. He explained to Horace Traubel: "my mother came partly of Quaker stock: all her leanings were that way-her sympathies: her fundamental emotional tendencies" (Traubel, 3:109). Van Velsor, like her mother, exhibited serenity (Allen, Solitary, 13), and she played the role of family peacekeeper by attempting to settle disputes that arose between Whitman and his father. Whitman loved Van Velsor "more than anyone else in the world," relying on that love to help him through difficult times (Allen, Solitary, 30).

The extent of the influence of his mother's temperament on him "could not be measured" or verbalized, Whitman said; "it can only be apprehended through the intuitions," through reading his poetry. "Leaves of Grass is the flower of her temperament active in me," he explains (Traubel, 2:113). The love of his mother for him blossoms within him and manifests itself in the love-"a kelson of the creation"19-he expresses for all people.

In addition to Van Velsor's emotional tendencies, Whitman also admired her physical characteristics. He saw his mother as an active, independent woman. Growing up on the family horse-breeding farm, Van Velsor was "a daily and daring rider" $(P W, 1: 8)$. She continued to be active and healthy as an adult, exhibiting a "splendid physique" and remaining "good-looking" until she died; moreover, she was "a hard worker" ( $D B N, 3: 659)$. Whitman could see how a woman's independent spirit benefited her physical health and allowed her to participate fully in life.

Van Velsor revealed her independence, too, in her speaking. Whitman explained that his mother "was very eloquent . . . very original in her manner, her style," not from schooling, however, for she was "illiterate in the formal sense." He remembered that she was "strangely knowing" and saw that she was freed from traditional modes of speaking (Traubel, 2:113-114). Thus, from childhood, Whitman had the oppor- 
tunity to associate with women whom he identified as Quaker and saw as loving, serene, and independent.

Characteristics that were apparent in Van Velsor and Williams, Whitman noted too in Quaker women outside his family, women like Lucretia Mott (1793-1880), Quaker minister, women's rights advocate, homemaker, and mother. ${ }^{20}$ To Traubel, Whitman expressed his admiration for these women:

Do you know Quaker women? The women are the cream of the sect. It was not Lucretia Mott alone-I knew her just a little: she was a gracious, superb character: but she was not exceptional: it distinguishes most of the women-seems to appear in them inevitably. (Traubel, 2:19)

Quaker women balanced family responsibilities with activities outside their homes. Whether married or single, they were expected "to heed the call" from God to serve in the ministry. ${ }^{21}$ Moreover, Quaker women regularly invited married and single Quakers of both sexes into their homes for intellectual discussions. ${ }^{22}$ Unmarried Quaker women, valued by other Quakers, "led full and balanced lives," working in jobs such as teaching so that they could live independently of their families. Quaker women remained serene in spite of their busy schedules. ${ }^{23}$ They viewed themselves as "instruments of the Spirit of God" (Stoneburner, 20). Margaret Hope Bacon explains that "the liberating sense of being led by the Spirit freed their lives from frenzy" (Mothers, 165).

Into his old age, Whitman praised Quaker women's independence. He admired Mary Whitall Smith Costelloe (1864-1945), a young Quaker woman who befriended him at Christmastime in $1882 .{ }^{24}$ She declared herself a "Whitmanite" after having read Leaves of Grass as a student at Smith, and she "took as [her] motto" the first two lines of Section 5 of "Song of the Open Road," in her words, "Henceforth I ordain myself loosed of all limits and imaginary lines / Going where I list, my own Master, total and absolute."25 Whitman knew about Costelloe's later work as a political activist in England and about the articles she had written in support of women's issues and suffrage. In 1889, he described her as "a true woman of the new aggressive type" and pointed to her "impetuosity, [and] ardor." He approved of her pursuing interests outside her home, explaining that doing so contributed to her increased sense of satisfaction whenever she worked in more traditional female roles. He emphasized that Costelloe was "abrogating nothing of her wifeliness, sisterliness, motherliness, womanliness"; instead, these features became enhanced in Costelloe (Traubel, 4:188-189). Thus, Whitman saw the Quaker woman as she viewed herself: as an active participant both within her home and outside it.

Whitman's association with women he identified as Quaker began in his early childhood. As a child, he also became acquainted with the spiritual teachings of Quaker minister Elias Hicks (1748-1830). Whit- 
man noted that his mother and his father, Walter Whitman (1789-1855), had taken him "more than once" to hear Hicks preach (PW, 2:627). Although his parents were not Quaker, they listened carefully to Hicks's sermons, and so did the young Whitman, who was so impressed that he promised himself he would some day write about Hicks ( $P W, 2: 627$ ). Whitman's November Boughs essay "Elias Hicks" (1888) fulfilled this commitment, and his long-standing affection for and admiration of Quakers is evident in the essay ( $P W, 2: 626-653)$.

Whitman recalled that when he and his parents heard Hicks preach in 1829 at Morrison's Hotel Ballroom in Brooklyn Heights, he, then around ten years old, saw about twelve Quaker elders, women and men, in their traditional Quaker costumes, sitting on a platform facing those attending, "[a]ll still as the grave." Then Hicks rose, stood in the silence, and spoke about the inner light ( $P W, 2: 636-638)$. The adult Whitman appears to have understood that Hicks had experienced a revelation of the inner light and spoke from the direction of truths revealed to him. Whitman explained that Hicks believed people must not submit to "outside doctrine of creeds, Bibles, legislative enactments, conventionalities, or even decorums, but are to follow the inward Deity-planted law of the emotional soul" ( $P W, 2: 639)$. Moreover, Whitman quoted Hicks's teaching: people could experience salvation only by obeying the truths revealed by "this inward light and law" (quoted in PW, 2:641). ${ }^{26}$ One's spiritual birth depended upon passively waiting for and acting from the direction of God's truths as they were revealed by the inner light.

An additional source for Whitman's knowledge of Hicks's beliefs is the Quaker minister's fournal. Whitman owned a copy of this work and incorporated passages from it into his essay "Elias Hicks" $(P W, 2: 635){ }^{27}$ Hicks explained his thinking about the inner light throughout his fournal. Whitman's explanations of these views in his essay about Hicks reveal his understanding of the concept of the inner light ( $P W, 2: 626-$ 653). In 1890, Whitman told Traubel that he subscribed to the teachings of Hicks regarding spirituality (Traubel, 7:430).

The religious views of both men were compatible, centering on what Quakers term the inner light. ${ }^{28}$ Hicks explained in his fournal that "the only sure foundation of true and real Christianity [is] the light within, or spirit of truth, the immediate revelation of the spirit of God, in the immortal souls of men and women" (412). He taught that God dwelled within each person (426), and Whitman agreed, employing, as did Hicks, language that includes both genders: "In the faces of men and women I see God, and in my own face in the glass ...." the narrator proclaims in Section 48 of "Song of Myself" (LG, 87). ${ }^{29}$ Furthermore, Hicks believed people could experience a revelation without the aid of ordained clergy (180)..$^{30}$ Concurring, Whitman declared in "Preface 1872 " that religion did not depend upon "Sundays and churches and church- 
going"; rather, religion emanated from within each woman and man, from "inside of all human character" $(L G, 473)$. Nothing "in the known universe [is] more divine than men and women," he proclaimed in "Preface 1855 " ( $L G, 719)$, and the divinity of every person empowered each to be his or her "own priest" ( $L G, 727)$.

Both Whitman and Hicks believed that the passive state is a necessary part of the process of salvation. To experience a revelation of God's truths, a person must first become passive. In "Manuscript Notebook2," written during the time Whitman was writing the 1855 Leaves of Grass, ${ }^{31}$ he stated that people could experience a birth of the truths that "lie waiting" within them. However, they could not force the truths to emerge; rather, they must wait for the truths to "unfold" from the soul of their own accord (UPP, 2:80). Similarly, Hicks taught that people could experience a revelation of God's truths by sitting in silence (336) and entering "into a passive state without a will of [their] own, as a little child" (323). After a time of silent waiting, an individual experienced a spiritual birth: "the new birth, or Christ formed in us" (103). People could choose salvation by freely submitting to the will of God as it was revealed to them; or they could choose sin by rejecting God's will to follow what Hicks termed their "independent will" (336). ${ }^{32}$

From the passive state, one became an active participant. Hicks did not see revelation as a one-time occurrence, however, but as "a continuous process" (Forbush, 176). Throughout his fournal, he described his many revelations and their effects upon his life. In meetings, he spoke spontaneously only those words revealed to him by God (296). Moreover, he followed God's lead as he journeyed forty thousand miles as a minister between 1779 and $1829 .{ }^{33}$ Whitman's explanation that Hicks "believ'd always . . . in the soul of man, invisibly rapt, ever-waiting, ever-responding to universal truths" $(P W, 2: 639 n)^{34}$ indicates the poet comprehended Hicks's view of the continuousness of revelation.

Whitman expresses belief in the continuousness of revelation in the 1855 edition of Leaves of Grass in lines that remained through succeeding editions with few changes. ${ }^{35}$ In what later became Section 46 of "Song of Myself," the speaker, like Hicks, travels "a perpetual journey" and urges his listeners to travel, each determining his or her own direction $(L G, 83)$. Furthermore, in what became Section 48 , the speaker receives a continuous revelation of God's word: "I find letters from God dropt in the street, and every one is sign'd by God's name, / And I leave them where they are, for I know that wheresoe'er I go, / Others will punctually come for ever and ever" $(L G, 87)$. Whitman's conception of revelation not as one instance of salvation but as a continuous process shows he understood how people could be both passive and active simultaneously and continuously. 
Understanding the reading of "passivity" as Quakers do is the key to clarifying apparent incongruities in Whitman's rendering of women. The woman who is "both passive and active" ( $L G, 97)$ - to use Whitman's words - is the focus of the two "Children of Adam" poems "I Sing the Body Electric" and "A Woman Waits for Me." 36 Section 5 of the former, which I will discuss first, has proven to be especially troublesome to some critics. Lawrence contends that the woman's madonna-like pose in the final line suggests her submission to childbearing and motherhood (617). Killingsworth in "Whitman and Motherhood" points to the inconsistency of this woman's "mystic" and "erotic" qualities, asserting, "The yoking of opposites, particularly 'passive and active,' results in meaninglessness" (38). He explains that the confusion readers see in Whitman's depictions of women can be attributed to Whitman's use of the conventional rhetoric of nineteenthcentury sentimental writing to present radical views about women (3032). And in his later work Whitman's Poetry of the Body, Killingsworth writes that the contradictions evident in Whitman's women reflect a familiar view of sexuality expressed by many nineteenth-century writers- that it is fine to engage in sexual activity if done with prudence (xvxvi). Killingsworth's analysis helps readers understand some of the confusion and contradictions surrounding Whitman's women. However, the woman who is both passive and active could be reconceived as an image of empowerment rather than simply a yoking of opposites if we look at the woman for qualities Whitman saw in Quaker women: serenity, independence, and lovingness.

In Section 5 of "I Sing the Body Electric," Whitman portrays both the spiritual revelations and sexual encounter of the male narrator and his female partner. Killingsworth rightly sees Whitman presenting the "physical and metaphysical" in this passage. Whitman's rendering of sexual intercourse reflects Victorian attitudes, Killingsworth explains, and from that perspective, the sex act can be viewed as sacred because it results in the birth of children and the "birth into manhood" of the male, his personality remaining incomplete until he experiences sexual intercourse with a woman (Poetry of the Body, 5-7). This explanation focuses on the physical and emotional development of the young male.

The role of the female, however, needs to be examined in more detail here, and the relationship between the spiritual and the physical experiences should be looked at more closely in a passage where Whitman deliberately portrays the two simultaneously. He once noted, "My two theses - animal and spiritual - became gradually fused in Leaves of Grass,-runs through all the poems and gives color to the whole" (NUPM, 383). His fusing of the spiritual and physical helps readers see the similarities between the two. Beginning with the first sixteen lines of the section, the male narrator presents his perception of his female partner: 
This is the female form,

A divine nimbus exhales from it from head to foot,

It attracts with fierce undeniable attraction,

I am drawn by its breath as if I were no more than a helpless vapor, all falls aside but myself and it,

Books, art, religion, time, the visible and solid earth, and what was expected of heaven or fear'd of hell, are now consumed,

Mad filaments, ungovernable shoots play out of it, the response likewise ungovernable,

Hair, bosom, hips, bend of legs, negligent falling hands all diffused, mine too diffused,

Ebb stung by the flow and flow stung by the ebb, love-flesh swelling and deliciously aching,

Limitless limpid jets of love hot and enormous, quivering jelly of love, white-blow and delirious juice,

Bridegroom night of love working surely and softly into the prostrate dawn,

Undulating into the willing and yielding day,

Lost in the cleave of the clasping and sweet-flesh'd day.

This the nucleus-after the child is born of woman, man is born of woman, This the bath of birth, this the merge of small and large, and the outlet again.

Be not ashamed women, your privilege encloses the rest, and is the exit of the rest, You are the gates of the body, and you are the gates of the soul. ( $L G, 96-97)$

The male's vision is obscured at first. He cannot see the female clearly, owing to the luminous cloud, or "divine nimbus" that surrounds her. Nor can he initially see his own soul, as suggested by the fact that following his salvation, he does see it, either anew, or for the first time. The narrator's clouded vision is caused by his submission to social forces that define and limit his life: "Books, art, religion, time, the visible and solid earth, and what was expected of heaven or fear'd of hell. . .."

In his "Manuscript Notebook-2," Whitman noted the importance of clear vision: "I am looking in your eyes,-tell me then, if you can, what is there more in the immortality of the soul more than this spiritual and beautiful miracle of sight?" This "miracle of sight" allowed one to see the "whelming splendor of the whole world" (UPP, 2:80-81), an action the male here is unable to perform.

Whitman could have constructed his male protagonist from ideas sparked from his reading of Hicks. Hicks noted that the vision of nonbelievers, "the dead" he called them (366), was blurred, and he employed terms such as "mists and fogs" (116), "shadows" (207), "curtain" (212), and "cloud" (233) to describe the elements that hindered their sight. ${ }^{37}$ Michael P. Graves explains that late seventeenth-century Quaker ministers employed five "clusters of metaphors" taken from the King James Bible: "Light/Dark," "Voice," "Seed," "Hunger/Thirst," and "Pilgrimage." Hicks's metaphors describing the hindered vision of non-believers are among those Graves includes in the "Light/Dark" meta- 
phor cluster. ${ }^{38}$ Whitman's "divine nimbus"-which prevents the male from seeing his own soul and the female's physical and spiritual qualities-functions in a manner similar to Hicks's metaphors. The "divine nimbus" metaphor could be included in the "Light/Dark" cluster of metaphors suggesting limited vision and those bringing to mind the opposite, the revelation of the inner light.

Hicks believed each person must follow the direction of truths revealed to him or her by the inner light rather than following one's own will or the demands of others. In the process of making this choice, those acting from the direction of God's truths gain insight into themselves and an understanding of others who also follow God's will. ${ }^{39}$ The fact that Whitman's male is unable to see clearly the female suggests he has not yet experienced a revelation of the inner light. The male partner in this poem is Whitman's rendering of one of those Hicks termed "the dead," one whose vision has not yet been cleared by a revelation of the inner light.

The male gives up what Hicks termed the "independent will" (336) to follow his partner's lead. Entering a passive state, he feels powerless in her presence, like "a helpless vapor." Next, he rejects those forces that define and limit his life: they "are now consumed." The female seems to move uninhibitedly: "Mad filaments, ungovernable shoots play out of [the female form]," and the male responds without restraint. Now the female joins her partner in a passive state: "Hair, bosom, hips, bend of legs, negligent falling hands all diffused, mine too diffused." Physically and spiritually, the male and female relinquish their independent wills to a higher power, and together they undergo spiritual births.

The male describes his and his partner's simultaneous experiences of spiritual revelation and sexual intercourse: "Bridgegroom night of love working surely and softly into the prostrate dawn, / Undulating into the willing and yielding day." From the darkness of night and spirtual death comes the light of day and life. The male is born spiritually of a woman. As one assisting him in his birth, the female can be viewed as a midwife. Graves explains that Quaker ministers have often been seen as midwives for bringing to life the inner light residing within each person (365). Discovering similarity between the female's two roles-giving physical birth to a child and assisting the male in his spiritual birth-the male notes that "after the child is born of woman, man is born of woman," and he tells his partner, "You are the gates of the body, and you are the gates of the soul." The male's revelation occurs with "the merge of small and large," that is, with the spontaneous movement of God's spirit into the male's own soul, an act Whitman helps readers visualize by joining it to the image of the male penetrating the body of the female during coitus. $^{40}$

As a result of his spiritual birth, the male protagonist's vision clears. Continuing through the final lines of the section, he explains: 
The female contains all qualities and tempers them,

She is in her place and moves with perfect balance,

She is all things duly veil'd, she is both passive and active,

She is to conceive daughters as well as sons, and sons as well as daughters.

As I see my soul reflected in Nature,

As I see through a mist, One with inexpressible completeness, sanity, beauty,

See the bent head and arms folded over the breast, the Female I see. $(L G, 97)$

The male now sees his own soul "reflected in Nature." Whitman stated that nature acted as a mirror, reflecting back to a person the source of his or her beliefs and actions (NUPM, 141). He suggests that the male, now looking within his own soul, sees the truths revealed to him during his spiritual birth. Rather than continuing to submit to social forces, he follows the direction of the inner light. The narrator's spiritual birth permits him to see everything anew. He is no longer one of "the dead."

In addition to seeing his own soul more clearly, the male gains a clearer perception of the female. One might argue that the male's vision has not cleared because "a mist" still obscures his view of her. However, he says, "I see through a mist" (my emphasis), suggesting he sees the female's "inexpressible completeness, sanity, beauty" - her serenityin spite of the mist. The male's repetition of the phrase "I see" a total of three times in the final three lines supports this reading. Moreover, he begins the final line with a fourth "See," and if one reads the line with an understood "you" as the subject, the male seems to be inviting readers to look with him at the female in the final pose, ending the section with one of the three "I see" phrases.

As the male sees his partner sitting quietly with her head bowed, her arms across her chest, he says of her that "she is both passive and active." The female's pose would not have been unusual for a Quaker: it suggests a person waiting passively and silently for a revelation of the inner light. For example, when Mott visited families in the early stages of her ministry, she sat "bowing her head in silence until she was moved to speak" (Bacon, Valiant Friend, 47). As a child, Whitman had seen Quakers sitting in silence when he went with his parents to hear Hicks preach at Morrison's Hotel Ballroom. The view of the woman in Section 5 of "I Sing the Body Electric" sitting passively at the end of the passage after she and her partner have just experienced a revelation suggests the continuousness of revelation and the woman's perpetual unity with God. Whitman's portrayal of the female as "both passive and active," then, is not the contradiction it seems.

In his revelation, the male observes that the "female contains all qualities." An examination of some of her qualities can help readers see Whitman's conception of the ideal woman. The portrayal of the female here suggests Whitman admired independent women. Although the fe- 
male conceives and bears children, Whitman does not limit her to these roles. The male's characterization of the female as "the bearer of the great fruit which is immortality" in the final line of the 1855 edition $^{41}$ does suggest the female's physical role of childbearing; however, it also indicates her spiritual role, that of a woman acting like a Quaker minister, assisting people to experience a spiritual birth and salvation.

The female is not only serene and independent, but loving as well. She expresses her love for her partner both spiritually and physically. Assisting the male in his salvation, she exhibits the kind of love Quakers feel for all people. Hicks explained, "Because the light is one in all, .. . it binds us together in the bonds of love" (quoted in Whitman, $P W$, $2: 640) .{ }^{42}$ And those who follow the direction of the light within them enter a "living faith which works by love" (Hicks, 332). In working for social reform, Quakers such as Mott and Costelloe lived their faith. Whitman saw, however, that Quaker women who focused on their families and homes also lived their faith and loved. His own mother, for example, "was beloved by all who met her" (Whitman, $D B N, 3: 659$ ), suggesting she evoked love in others by exhibiting a love for them. Although not formally a Quaker, Van Velsor seems to have imparted to her son an important principle of Quakerism: a love for all people.

In addition, Whitman portrays the female as a loving and active sexual partner. She leads the male into a sexual encounter that seems to include multiple instances of sexual intercourse between them in a "[b]ridegroom night of love" that continues until dawn. The female's active participation in a sexual relationship with her partner reflects the positive view of sexuality Whitman expressed in his prose. In "Manuscript Notebook-4," he declared sexual desire between a woman and a man good and normal: "Most of what is called delicacy is filthy or sick and unworthy of a woman of live rosy body and a clean affectionate spirit" (UPP, 2:90). Furthermore, in an 1856 letter to Emerson, Whitman denounced not merely the negative connotations of sexuality but also the view that sexual activity should be avoided, and he criticized "the fashionable delusion of the inherent nastiness of sex, and . . the feeble and querulous modesty of deprivation" promoted by some ( $L G$, 737). Harold W. Blodgett and Sculley Bradley believe that Whitman's letter can be seen as a preface to the 1856 Leaves of Grass since he included it in that edition (in Whitman, $L G, 730$ n). It seems, then, that Whitman used the letter to Emerson to state publicly his opposition to those in society who not only denied the existence of women's sexuality but also discouraged women from full and active participation in sexual intercourse.

Whitman's view of the sinlessness of sexual intercourse within marriage exhibits similarities to Hicks's ideas about sexuality. The Quaker minister did not see sexual activity itself as sinful, explaining "all that [God] wills and creates is immutably good, agreeably to his own decla- 
ration in the work of creation; hence, whatever he ordains must likewise be immutably good" (161). However, the body must not go unrestrained. Bliss Forbush explains that Hicks taught that the soul maintained "the desires and passions of the body within the bounds of reason and truth" by following the direction of the inner light. In this way, one remained free of $\sin$ in sexual matters. ${ }^{43}$

Although Whitman believed in the equality of the body and soul rather than the soul's authority over the body ("Song of Myself," $L G$, 32), he agreed with Hicks that sexual activity should not be without restrictions. Whitman asserted that the partners themselves should control their relationship. He pointed out that love does not require the supervision of "censors, monitors, guardians" (Traubel, 2:331). Aspiz explains that Whitman wanted both partners to experience passion, and that would occur, Whitman believed, if the couple practiced "virtuous marital continence": engaging in sexual intercourse only when the woman was most likely to be fertile. The woman decided whether or not to participate since, Whitman maintained, she controlled the sexual relationship in which she was engaged. ${ }^{44}$ By determining their own sexual behavior from the truths revealed within each of them by the inner light, the male and female, like the partners in Section 5 of "I Sing the Body Electric," would be freed from the negative social attitudes and restrictions surrounding sexual activity, and they could unreservedly express their passion for each other.

The male protagonist of this passage of "Body Electric" sees his partner's lovingness as well as her serenity and independence, and he is aware that these characteristics are the result of her being "both passive and active." The female experiences the continuous process of passively waiting for and acting from the direction of the inner light, submitting to the will of God rather than to social forces that limit life. The male observes, too, that she "contains all qualities" and that she is "One with inexpressible completeness, sanity, beauty." She exhibits characteristics of nineteenth-century Quaker women who "set a pattern of wholeness for the women of their age" (Bacon, Mothers, 165).

Whitman's rendering of the passive and active woman appears again in "A Woman Waits for Me." Killingsworth correctly shows that Whitman's women are created from a variety of cultural influences, and in this poem they are molded from ideas Whitman found in eugenics and phrenology. Killingsworth points to these two influences as sources of the contradiction and confusion he sees in Whitman's women. He states that "when Whitman tries to unite the volatile sexual female and the great mother, the two figures collide rather than meld" (Poetry of the Body, 69-70; "Motherhood," 36-37). But an alternative view comes to light when the women in the poem are looked at from the perspective of another cultural influence, Quakerism. As the poem begins, the male protagonist points to the qualities he admires in women: 
A woman waits for me, she contains all, nothing is lacking,

Yet all were lacking if sex were lacking, or if the moisture of the right man were lacking.

Sex contains all, bodies, souls,

Meanings, proofs, purities, delicacies, results, promulgations,

Songs, commands, health, pride, the maternal mystery, the seminal milk,

All hopes, benefactions, bestowals, all the passions, loves, beauties, delights of the earth,

All the governments, judges, gods, follow'd persons of the earth,

These are contain'd in sex as parts of itself and justifications of itself.

Without shame the man I like knows and avows the deliciousness of his sex,

Without shame the woman I like knows and avows hers.

Now I will dismiss myself from impassive women,

I will go stay with her who waits for me, and with those women that are warm-

blooded and sufficient for me,

I see that they understand me and do not deny me,

I see that they are worthy of me, I will be the robust husband of those women.

They are not one jot less than I am,

They are tann'd in the face by shining suns and blowing winds,

Their flesh has the old divine suppleness and strength,

They know how to swim, row, ride, wrestle, shoot, run, strike, retreat, advance, resist, defend themselves,

They are ultimate in their own right-they are calm, clear, well-possess'd of themselves. (LG, 101-102)

Speaking of Whitman's women in general, and echoing language in the first two lines of this poem, Killingsworth contends, "Whitman's women seem always to desire sexual nourishment, which only the semen of the right man can provide - a notion that ... underscores Whitman's (defensive) belief that female sexuality is incomplete, is lacking" (my italics). I agree with Killingsworth's assessment that the "twenty-ninth bather" exemplifies a woman whose sexuality is incomplete (Poetry of the Body, 78). However, I see her as spiritually and emotionally incomplete, as well. Whitman in his editorials (as discussed earlier) pointed out that poor physical and emotional health limited the lives of many married women and the lives of their husbands and that women's inability to experience joy weakened the relationships (ISL, 117-118). These sickly women appear in this poem as the women in whom "all were lacking." The male protagonist of "A Woman Waits for Me" labels them "impassive" and later rejects them as potential sexual partners since they seem unlikely to be able to actively participate in a sexual relationship.

In contrast, the woman who waits for the male protagonist is complete; "she contains all," he explains. These words bring to mind the 
description of the woman in Section 5 of "I Sing the Body Electric": "The female contains all qualities"; "she is both passive and active"; and she is "One with inexpressible completeness." Whitman emphasizes the completeness of the passive and active woman in "A Woman Waits for Me," just as he does in "Body Electric," by focusing on both her physical and spiritual qualities. It does appear that the male is saying that this woman would be incomplete if she did not engage in sexual intercourse, or if she did not contain the semen "of the right man." However, the male's next statement, "Sex contains all, bodies, souls ...," suggests otherwise: it is another illustration of Whitman's fusing of the spiritual and physical. I have shown in my discussion of Section 5 of "Body Electric" how the male sees his partner's completeness after she has acted like a Quaker minister and spiritual midwife, assisting him in his spiritual birth, an act Whitman portrays as sexual intercourse between the partners; in addition, she is capable of giving birth to children. The female in that passage is complete because she "contains all qualities" - spiritual and physical — and she is "both passive and active," in perpetual unity with God $(L G, 96-97)$. I propose a similar reading of the female who "contains all" in "A Woman Waits for Me."

When Whitman says of some women in "A Woman Waits for Me" that "all were lacking if sex were lacking, or if the moisture of the right man were lacking," he means these women are incomplete because they have not yet experienced a union of the spiritual and physical within them, an entering of the soul into the body. Therefore, they lack a unity with God and with other women and men. ${ }^{45}$ As I have shown above, completeness is a result of the continuous act of passively waiting for and acting from the direction of the inner light in all matters, including sexual activity, a relationship the male protagonist of these two "Children of Adam" poems appears to understand.

The male protagonist admires men and women who exhibit confidence in themselves as sexual beings. He states, "Without shame the man I like knows and avows the deliciousness of his sex, / Without shame the woman I like knows and avows hers." Killingsworth asserts that Whitman's decision to employ the elliptical structure "hers" rather than repeat for the female "the deliciousness of her sex" suggests that Whitman felt "a slight hesitancy to allow that women have sexual instincts as fully developed as males" (Poetry of the Body, 69-70; "Motherhood," 37 ). But I see in the narrator's statement Whitman's and Hicks's views that sexual desire between a woman and man is good and normal and that both partners have the freedom to experience passion within the limits set by them. Moreover, the male's explanation that this woman "avows [the deliciousness of her sex]" suggests she is one of the women who "contains all," and that one of the things she contains is sex. He goes on to note that "Sex contains all," including "bodies, souls," and "all the passions, loves, beauties, delights of the earth." The male's fo- 
cus on the female in this passage implies the list is especially applicable to women, although he does not specify either sex.

The male will form a relationship with a woman who exhibits qualities similar to those of Quaker women with whom Whitman was familiar. These women are loving. Following the thinking of Hicks and Whitman, they see their sexuality in a positive light, "[w]ithout shame." The fact that they are "warm-blooded and sufficient for [the male]" points to their good health, an attribute that allows each to physically express love and receive the physical manifestation of the love of her partner. Like Whitman's mother and the traveling Quaker ministers, these women participate in outdoor physical activities that contribute to their good health. They "know how to swim, row, ride, wrestle, shoot, run, ... defend themselves," and "[t]hey are tann'd," and their skin is pliant and strong. The male protagonist asserts that the women he desires are independent, "ultimate in their own right," bringing to mind Whitman's observations of Costelloe, Van Velsor, and other Quaker women. And giving expression to Whitman's and Quakers' views of the equality of women and men, the male proclaims, "They are not one jot less than I am." Finally, the male notes their serenity and confidence: "they are calm, clear, well-possess'd of themselves," qualities that Whitman observed in Quaker women such as Mott. The woman who waits for the male in the poem "contains all." $\mathrm{He}$ and his partner can express their passion for each other without restraint, developing spiritual unity in addition to physical unity as did the male and female in Section 5 of "Body Electric."

Critics have reacted strongly to Whitman's portrayal of the sexual encounter in the following passage from "A Woman Waits for Me":

I draw you close to me, you women,

I cannot let you go, I would do you good,

I am for you, and you are for me, not only for our own sake, but for others' sakes,

Envelop'd in you sleep greater heroes and bards,

They refuse to awake at the touch of any man but me.

It is I, you women, I make my way,

I am stern, acrid, large, undissuadable, but I love you,

I do not hurt you any more than is necessary for you,

I pour the stuff to start sons and daughters fit for these States, I press with slow rude

muscle,

I brace myself effectually, I listen to no entreaties,

I dare not withdraw till I deposit what has so long accumulated within me. ( $L G, 102-$ 103)

Killingsworth sees "a double standard" in Whitman's rendering of "an ideal sexual couple" here. Killingsworth explains that the male has claimed earlier in the poem that he sees the women who wait for him as 
his equal, yet the male behaves aggressively as he tries to convince the women to engage in a sexual relationship with him ("Motherhood," 3637). Erkkila sees a contradiction between Whitman's depiction of women as equal to men earlier in the poem and his portrayal here of a sexual encounter that resembles "the scene of domestic rape" (137-138). Edwin Haviland Miller calls this passage "a masturbatory rape dream" that focuses "upon power over a reluctant victim" (136-137). All three of these views assume the male forces his partner, causing her pain.

However, I see in this scene the love and mutuality of the partners rather than rape. The male declares to her, "I am stern, acrid, large, undissuadable, but I love you," revealing the emotional and physical manifestations of his love. His use of the word "undissuadable" emphasizes his desire to physically express his love for his partner and shows his wish that she not be one of the "impassive women" who would consistently reject his sexual advances. If the female rejects him consistently, the male protagonist would be inhibited from fully expressing to his partner his emotional and physical love for her. Although Whitman is speaking of the Quaker love for all people in this next statement, the concept he expresses can be applied to the passage above in light of his assertion that he deliberately fuses the physical and the spiritual throughout his poetry. He muses, "It is a singular feature in men, that to simply confess a love is not enough: there must be some concrete manifestation of it" (Traubel, 3:209).

Mutuality is evident as the male protagonist takes into account his partner's physical and emotional needs, assuring her, "I am for you, and you are for me," reflecting Whitman's and Hicks's views that both the female and the male can freely experience passion within the limits they set as they follow the direction of the inner light. Even though the male is "undissuadable," he exhibits restraint in the sexual encounter, focusing on his partner's needs and upon her responses to his actions. He limits his actions to those fulfilling her desire for him, assuring her, "I do not hurt you any more than is necessary for you." Evidence from the 1855 edition of Leaves of Grass suggests that Whitman saw "hurt" as one of the characteristics of sexual intercourse, not as an intention to inflict pain on one's partner. In Section 21 of the 1892 edition of "Song of Myself," the speaker says:

Far-swooping elbow'd earth — rich apple-blossom'd earth!

Smile, for your lover comes.

Prodigal, you have given me love- therefore I to you give love!

O unspeakable passionate love. (LGVar., 27-28) ${ }^{46}$

The lines above first appeared in the 1855 edition but with two additional lines that Whitman ultimately cut. In them, the speaker says to his lover: 
Thruster holding me tight and that I hold tight!

We hurt each other as the bridegroom and the bride hurt each other. (LGVar., 28n)

Killingsworth states these lines seem to portray "a homosexual encounter tinged with sadomasochistic delight" (Poetry of the Body, 152). But I believe that Whitman is depicting the speaker's mutual and reciprocal "passionate love" with the earth in the metaphor of a sexual encounter between two people physically expressing the emotional commitment they have made to each other in marriage. The speaker's unity with the earth is like that of two people on their wedding night. And in that passion, both partners experience "hurt." The word "hurt" in "A Woman Waits for Me" has a similar connotation-Whitman's perception of the characteristic physical sensations of a woman and man engaged in sexual intercourse on their wedding night.

The male and his female partner in "A Woman Waits for Me" participate in a sexual relationship characterized by the mutual expression of love. Following the direction of the inner light frees women and men from social restrictions surrounding sexuality yet restrains them at the same time. If the male's partner were one of the "impassive women," he would not have been able to express physically his love for her, owing to the woman's poor health and her inability to act spontaneously from emotion. If he did act on his sexual desire for an "impassive" partner, then the sexual encounter Whitman depicts in "A Woman Waits for $M e$ " could indeed be seen as the rape Erkkila has suggested. The male, however, wants as his partner a woman who "contains all," one who can unite with him in a sexual relationship of mutual passion and joy.

The women in "A Woman Waits for Me" and in Section 5 of "I Sing the Body Electric" are free to develop physically and spiritually, and they actively participate in life. They can do so because they experience the continuous process of passively waiting for and acting from the direction of God's truths as they are revealed by the inner light. These women submit to the will of God rather than to social forces that limit life. What appears to some critics as women's passive submission to social forces in these two poems really is an empowered rendering of women as active participants. Further study of the women in Whitman's poetry in the context of his spiritual views and of the Quakers with whom he was familiar will likely reveal other examples and add to the picture of Whitman's ideal woman as serene, independent, and loving - a woman who is complete.

Pierce College, Lakewood, Washington 


\section{NOTES}

This project was inspired in part by the genealogy and history of my own Quaker ancestors (Robert Spring, "Ancestors and Descendants of Anna [Parker] Butler," unpublished manuscript, 1982).

1 "Health Among Females," Brooklyn Daily Times, in Walt Whitman, I Sit and Look Out: Editorials from the Brooklyn Daily Times, ed. Emory Holloway and Vernolian Schwarz (New York: Columbia University Press, 1932; rpt., New York: AMS Press, 1966), 116-117, hereafter cited in the text as ISL. "Health Among Females" is dated October 17, 1858 (Whitman, ISL, 117); however, Sherry Ceniza notes December 17, 1858, as the correct date, "Walt Whitman and Abby Price," Walt Whitman Quarterly Review 7 (1989), 66-67.

2 "Female Health," Brooklyn Daily Times, March 31, 1859, in Whitman, ISL, 117118.

3 "Can All Marry?," Brooklyn Daily Times, June 22, 1859, in ISL, 121-122. In the 1855 edition of Leaves of Grass Whitman portrays the "twenty-ninth bather," a woman exhibiting characteristics of the woman alone. Later becoming Section 11 of "Song of Myself," this passage is one of the most critically studied in Whitman's poetry, and it remained relatively unchanged in subsequent editions; see Walt Whitman, Leaves of Grass: A Textual Variorum of the Printed Poems, ed. Sculley Bradley, Harold W. Blodgett, Arthur Golden, William White, 3 vols. (New York: New York University Press, 1980), $1: 12 \mathrm{n}-13 \mathrm{n}$, hereafter cited in the text as LGVar. For a recent discussion of this woman and extensive references to other critical studies of the passage see Maire Mullins, "Leaves of Grass as a 'Woman's Book," Walt Whitman Quarterly Review 10 (1993), 195-208. See also M. Jimmie Killingsworth, Whitman's Poetry of the Body: Sexuality, Politics, and the Text (Chapel Hill: University of North Carolina Press, 1989), 31-34, abbreviated hereafter as Poetry of the Body; Edwin Haviland Miller, Walt Whitman's Poetry: A Psychological fourney (New York: New York University Press, 1968), 93-94; and Robert K. Martin, "Whitman's Song of Myself: Homosexual Dream and Vision," Partisan Review 42 (1975), 90-91.

4 "The Women of the West" (1882) in Walt Whitman, Prose Works 1892, ed. Floyd Stovall, 2 vols. (New York: New York University Press, 1963-1964), 1:225-226, hereafter cited parenthetically in the text as $P W$.

5 Democratic Vistas (1871) in Whitman, $P W 2: 389,401$.

6 See Harold Aspiz, "Walt Whitman, Feminist," in Walt Whitman: Here and Now, ed. Joann P. Krieg (Westport: Greenwood Press, 1985), 79; Betsy Erkkila, Whitman the Political Poet (New York: Oxford University Press, 1989), 257-258; Muriel Kolinsky, “'Me Tarzan, You Jane?': Whitman's Attitudes Toward Women from a Women's Liberation Point of View," Walt Whitman Review 23 (1977), 158, 165; Kay F. Reinartz, "Walt Whitman and Feminism," Walt Whitman Review 19 (1973), 128; and Judy Womack, "The American Woman in 'Song of Myself," Walt Whitman Review 19 (1973), 67, 69. For an extensive review of critical studies about Whitman's portrayals of women, see Mullins, 195-208. Sherry Ceniza's recent study, Walt Whitman and 19th-Century Women Reformers (Tuscaloosa: University of Alabama Press, 1998), with extensive examinations of Louisa Van Velsor Whitman, Abby Hills Price, Paulina Wright Davis, and Ernestine L. Rose, appeared after my essay was completed.

7 D. H. Lawrence, "Whitman," Nation and the Athenaeum 29 (1921), 617.

8 Arthur Wrobel, “'Noble American Motherhood': Whitman, Women, and the Ideal Democracy," American Studies 21, no. 2 (1980), 14. 
9 Myrth Jimmie Killingsworth, "Whitman and Motherhood: A Historical View," American Literature 54 (1982), 30, 38, 36, abbreviated hereafter as "Motherhood"; and Poetry of the Body, 78.

10 Robyn Wiegman, "Writing the Male Body: Naked Patriarchy and Whitmanian Democracy," Literature and Psychology 33, nos. 3-4 (1987), 16-18.

11 W[illiam] S[loane] Kennedy, "The Quaker Traits of Walt Whitman," Conservator July 1890,36 . According to Whitman, Kennedy was the first to publish information about the influence of Quakerism on the poet's beliefs. Whitman had read a draft of the article before it was published and was pleased with it (Horace Traubel, With Walt Whitman in Camden, vol. 7, fuly 7, 1890-February 10, 1891, ed. Jeanne Chapman and Robert MacIsaac [Carbondale: Southern Illinois University Press, 1992], 1-2). Citations to this and the following volumes of Traubel's work will be made by volume and page number in my essay: vol. 1, March 28-fuly 14, 1888 (1905; rpt., New York: Rowman and Littlefield, 1961); vol. 2, Fuly 16-October 31, 1888 (1907; rpt., New York: Rowman and Littlefield, 1961); vol. 3, November 1, 1888-fanuary 20, 1889 (1912; rpt., New York: Rowman and Littlefield, 1961); vol. 4, fanuary 21-April 7, 1889, ed. Sculley Bradley (Philadelphia: University of Pennsylvania Press, 1953). Quakers have considered women equal to men since George Fox founded the faith in 1652, their egalitarian views stemming from the belief that all people are capable of experiencing salvation by following God's truths as they are revealed to each person (Margaret $\mathrm{H}$ [ope] Bacon, As the Way Opens: The Story of Quaker Women in America [Richmond, IN: Friends United Press, 1980], 2-4).

12 Lawrence Templin, "The Quaker Influence on Walt Whitman," American Literature 42 (1970), 165-180; Gay Wilson Allen, The New Walt Whitman Handbook (New York: New York University Press, 1975), 162-163. For additional information on Whitman's religious background, see Gay Wilson Allen, The Solitary Singer: $A$ Critical Biography of Walt Whitman (New York: Macmillan Company, 1955), 7-8, 20, abbreviated hereafter as Solitary.

13 Reinartz, 129-132. Whitman presented these four women as alternates to the "stock feminine characters" of novels and poetry: the "princesses, or ladies" that most nineteenth-century women and men saw as ideal women. A young woman from a large, poor family happily supports herself, first as a seamstress, and then as a housekeeper, sending money home to her family and finding jobs for her sisters. The woman who operates a "mechanical business" maintains her "coolness and decorum" in the face of "the coarseness" of those with whom she conducts business. The wife of a mechanic and mother of two children happily cares for her family and home as she pursues interests outside her home. The wise eighty-year-old "Peacemaker" lovingly settles disputes arising in her community $(P W, 2: 400-401)$.

14 Walt Whitman, Notebooks and Unpublished Prose Manuscripts, ed. Edward F. Grier, vol. 1 (New York: New York University Press, 1984), 31, hereafter cited in the text as NUPM.

\section{Allen, Solitary, 13.}

16 Walt Whitman, Daybooks and Notebooks, ed. William White, 3 vols. (New York: New York University Press, 1978), 1:267n. White quotes Whitman in this note (1:265n268n). Hereafter, Daybooks and Notebooks will be cited in the text as $D B N$.

17 Here in "Two Old Family Interiors" Whitman quotes his friend John Burroughs (in PW, 1:9), who wrote Notes on Walt Whitman as Poet and Person (1867) to which Whitman contributed (Allen, New Walt Whitman Handbook, 5). 

of Friends (New York: St. Martin's Press, 1973), 76, 79.

19 Walt Whitman, Leaves of Grass, Comprehensive Reader's Edition, ed. Harold W. Blodgett and Sculley Bradley (New York: New York University Press, 1965), 33. Unless otherwise noted, quotations from Leaves of Grass are taken from this edition and hereafter cited as $L G$.

20 Whitman could have heard about Mott from several sources. Ceniza notes that Whitman's close friend Abby Price (1814-1878) provided him with "one of the richest resources possible for understanding the issues underlying the early women's rights movement in America" (49-51). Whitman's association with Emerson is another. Bacon notes that Mott was acquainted with Emerson and other Transcendentalists (Margaret H[ope] Bacon, The Quiet Rebels: The Story of the Quakers in America [New York: Basic Books, 1969], 107). Mott knew something of Whitman's style and subject matter in Leaves of Grass (Frederick B. Tolles, "A Quaker Reaction to Leaves of Grass," American Literature 19 [1947], 170-171), and she admired his work (Margaret Hope Bacon, Valiant Friend: The Life of Lucretia Mott [New York: Walker and Company, 1980], 159). Whitman possibly read Mott's speeches. According to Bacon, and Dana Greene, some were published by Fowler and Wells, the New York Times, and the New York Herald Tribune ("Principal Sermons and Speeches of Lucretia Mott," in Bacon, Valiant Friend, 251-254). Fowler and Wells was the primary distributor of the 1855 Leaves of Grass (Allen, Solitary, 149). For the texts of many of Mott's speeches, see Dana Greene, ed., Lucretia Mott: Her Complete Speeches and Sermons (New York: Edwin Mellen Press, 1980).

21 Susan Mosher Stuard, "Women's Witnessing: A New Departure," in Witnesses for Change: Quaker Women Over Three Centuries, ed. Elisabeth Potts Brown and Susan Mosher Stuard [New Brunswick: Rutgers University Press, 1989], 16-17). Quaker women traveled and preached in the ministry from the early days of the faith. Mary Fisher and Anne Austin were the first Quaker missionaries to come to America, arriving in Boston from England in 1656 (Phyllis Mack, "Gender and Spirituality in Early English Quakerism, 1650-1665," in Brown and Stuard, 32-33). Mott traveled and preached throughout the northeastern United States beginning in 1830, and the six Mott children were cared for by their maternal grandmother, Anna Folger Coffin, or by Anna, the eldest child (Bacon, Valiant Friend, 49-51). Whitman commented on the discourse of women ministers in his Brooklyn Daily Times editorials. In "A Woman in the Pulpit," May 17, 1858, he indicated his approval of female preachers and noted the success of Rev. Lydia A. Jenkins, a Universalist (ISL, 79-80). In "A PreacheressHicksite Quakers," May 27, 1858, Whitman pointed out that Rachel Baker spoke with conviction before the annual meeting at the Hester Street Meeting House (ISL, $80)$.

22 Carol Stoneburner, "Introduction: Drawing a Profile of American Female Public Friends as Shapers of Human Space," in The Influence of Quaker Women on American History: Biographical Studies, ed. Carol Stoneburner and John Stoneburner (Lewiston, NY: Edwin Mellen Press, 1986), 24.

23 Margaret Hope Bacon, Mothers of Feminism: The Story of Quaker Women in America (San Francisco: Harper \& Row, Publishers, 1986), 59, 165, abbreviated hereafter as Mothers; and Quiet Rebels, 146.

24 Allen, Solitary, 509. See also Barbara Strachey, Remarkable Relations: The Story of the Pearsall Smith Family (London: Victor Gollancz Ltd., 1980); rpt. as Remarkable Relations: The Story of the Pearsall Smith Women (New York: Universe Books, 1982), 65-67. 
25 Mary Berenson, Mary Berenson: A Self-Portrait from her Letters E Diaries, ed. Barbara Strachey and Jayne Samuels (New York: W. W. Norton \& Company, 1983), 36. White notes that Mary Whitall Smith's first husband was Benjamin Francis Conn Costelloe (in Whitman, $D B N, 2: 342 \mathrm{n}$ ), and Strachey and Samuels state that after the death of her first husband, Costelloe married Bernard Berenson (in Berenson, 13).

26 Stovall (in Whitman, $P W, 2: 640$ n) notes that Whitman quoted here from Hicks's 1830 letter to Hugh Judge, a piece included in Hicks's fournal. See appendix to Elias Hicks, Fournal of the Life and Religious Labours of Elias Hicks. Written by Himself, 5 th ed. (New York: Isaac T. Hopper, 1832; rpt., New York: Arno Press, 1969), 439-442, hereafter cited parenthetically in the text.

27 Floyd Stovall, The Foreground of Leaves of Grass (Charlottesville: University Press of Virginia, 1974), 49. See Stovall (in Whitman, $P W, 2: 626 \mathrm{n}$ ) for further information about Whitman's use of Hicks's fournal as a source for this essay.

28 For discussion of parallels between Whitman's religious beliefs and the Quaker concept of the inner light, see Templin, 165, and Howard W. Hintz, The Quaker Influence in American Literature (1940; rpt., Westport: Greenwood Press, 1970), 6669.

29 This line appeared in the 1855 edition, as well (LGVar., 1:79).

30 In Quaker meetings for worship, any person could stand to speak God's word; there was no paid ministry. However, those who exhibited a special aptitude for speaking were seen as "ministers" (Elisabeth Potts Brown and Jean R. Soderlund, "Sources on Quaker Women," in Brown and Stuard, 158).

31 For information on the dating of this notebook, see Holloway's note in Walt Whitman, The Uncollected Poetry and Prose of Walt Whitman, ed. Emory Holloway, 2 vols. (New York: Peter Smith, 1932), 2:79n. Hereafter, this work will be cited in the text as UPP.

32 See also Bliss Forbush, Elias Hicks: Quaker Liberal (New York: Columbia University Press, 1956), 78-79.

33 Forbush, xii, 290-292. Whitman noted the length and duration of several of Hicks's journeys in his essay about Hicks ( $P W, 2: 634,636)$.

34 Whitman's note.

35 LGVar., 1:74-75, lines 1202, 1210-1211; 1:79, lines 1286-1288.

36 "I Sing the Body Electric" precedes "A Woman Waits for Me" in the 1892 edition of Leaves of Grass. The former poem was first published in 1855, untitled, and in 1856 as "Poem of the Body"; the latter was first published in 1856 as "Poem of Procreation" (Blodgett and Bradley in Whitman, LG, 92n, 100n).

37 Forbush explains that Hicks, in the tradition of Quaker ministers, used "the peculiar Quaker phraseology" that included these metaphors (165). Hicks was familiar with the style and content of the writing of the early Quakers since he had studied their published journals as part of his education, a practice common among young Quakers (Forbush, 155).

38 Michael P. Graves, "Functions of Key Metaphors in Early Quaker Sermons, 1671-1700," Quarterly Fournal of Speech 69 (1983), 366-368.

39 For example, Quaker women helped other women in their meeting to carry out their "witness," even if they did not believe in it themselves (Stuard, in Brown and 
Stuard, 17). And Quaker husbands cared for large families of young children while their wives traveled as ministers both within their own countries and overseas, often for months or even years at a time (Bacon, Mothers, 36-41, 169-171).

40 Critics have noted the sexual experience and spiritual revelation of the speaker in Section 5 of "Song of Myself." See Blodgett and Bradley's note in Whitman, LG, 32n; Erkkila, 97-98; Killingsworth, Poetry of the Body, 39-43; and James E. Miller, Jr., A Critical Guide to Leaves of Grass (Chicago: University of Chicago Press, 1957), 1011.

41 This line was ultimately cut. See LGVar., 1:126n.

42 Stovall notes that the source of this sermon is unknown, in Whitman, $P W, 2: 640 \mathrm{n}$.

43 Forbush, 78-79. Frost, in his study of American Quakers between 1672 and circa 1815, explains that sexual intercourse between partners who followed the inner light was not considered sinful and that children conceived within such a union were seen as "a blessing from God and not an effect of sin" $(66,179)$.

44 Harold Aspiz, Walt Whitman and the Body Beautiful (Urbana: University of Illinois Press, 1980), 200-201, 230.

45 In the spiritual revelation that Whitman depicts in Section 5 of "Song of Myself," the protagonist feels boundaries removed when the body and soul unite, and he explains, "Swiftly arose and spread around me the peace and knowledge that pass all the argument of the earth." He feels united with God and with all men and women, and knows that love is "a kelson," a foundation, of this unity ( $L G, 32-33)$.

46 These lines appeared in the 1855 edition, and they remained through succeeding editions with some changes made in the punctuation and capitalization (LGVar., $27 n-28 n)$. 